\title{
An Irish diasporic translator: Louise Swanton Belloc and the diffusion of Irish writing in 19th-century France.
}

\author{
Raphaël Ingelbien
}

KU Leuven

\begin{abstract}
Translation rarely features in modern Irish diaspora studies, which have sometimes been accused of an Anglocentric monolingual bias. This article explores possibilities for a renewed attention to Irish diasporic translators in the modern period by recovering the neglected figure of Louise Swanton Belloc (1796-1881), the daughter of an officer in the Irish Brigades in France. Besides producing French versions of English classics, Swanton Belloc did much to disseminate Irish writing and promote Irish causes in 19th-century France. An examination of several translations and of their paratextual apparatus charts Swanton's evolution as a diasporic translator, from an early translation that was categorised as English literature by her French publisher to an increasing assertion of the Irish dimension of the translated material - sometimes bringing out Irish features that were only latent in the original. The discussion of Swanton Belloc's choices and strategies as a translator of and commentator on Irish writing is complemented by references to personal archival material that survives. Finally, the Franco-Irish translator's twofold affiliation to Irish causes and to the English language underscores the paradoxes of mediators whose bilingualism provides an interface between more than two national cultures. Her case suggests that diasporic translation can both find inspiration in and unsettle notions of origins, Irish or other.
\end{abstract}

Keywords: diaspora; translation; paratext; Louise Swanton Belloc; Irish nationalism

The long history of Irish emigration raises questions about the scope of translation in Ireland. To the extent that migrant translators still identify as Irish, do they count as Irish translators? If, to use Mary Robinson's famously inclusive view of the nation, Ireland includes seventy million people scattered across the globe, translation activities among the Irish diaspora should be granted a legitimate place in analyses of Irish translation. Diaspora and translation seem intuitively linked: as Anne O'Connor (2017) notes, diaspora studies is one of the disciplines that "have regularly theorised a transnationalism in dialogue with translation", as "[t]hrough migration, travel, interactions, influence and networks, cultures are 'translated' into new, often hybrid forms in a transnational flow of ideas, practices and people" (3). The quotation marks around O'Connor's use of the term, however, highlight an essentially metaphorical connection between translation and diaspora: while on an international level, migrants as translators have become a focus of attention (see e.g. Polezzi 2012), it is striking how little work has yet been done either to discuss diasporic figures within Irish translation studies or, conversely, to consider translators as significant individuals within Irish diasporas.

The lacuna undoubtedly has much to do with still dominant perceptions of the global Irish diaspora as the result of mass movements out of Ireland since the nineteenth century. The " 70 
million people' of Irish descent famously evoked by then President Mary Robinson in 1995 chiefly live in the United States, Britain, or former settler colonies whose official language is English. Many already spoke English when they left Ireland, or became part of anglophone Irishspeaking communities abroad; the near-absence of an Irish-language print culture before the advent of the Gaelic League would have been a challenge for any aspiring Irish-speaking translator in the period. Any 'translation' that such modern Irish diasporic migrants were involved in has more to do with the etymological root of the term in the Latin for 'transfer' than with the linguistic transposition of written texts. Michael Cronin (2008) has observed that

there has been much talk about the Irish diaspora and subsequently about Ireland as one of the most globalized countries on the planet. However, a great deal of the attention on Ireland's relations with elsewhere is bound up with the anglophone world. (183)

Cronin consequently called for more attention to Irish writing in translation in order to achieve a "diffusive perspective" on the global reach of Irish culture that would not be bound by the linguistic limitations of a "predominantly Anglocentric diasporic purview" (184).

Such wariness towards the implicit linguistic exclusiveness of Irish diaspora studies seems largely justified with regard to modern and contemporary experience. Earlier Irish diasporas did however move in a more multilingual world; as Cronin himself noted elsewhere (2006, 23-24), the mediaeval Irish monks and later Catholic and Jacobite exiles who spread out across much of Europe included some notable translators. But while issues of translation and multilingualism have occasionally featured in scholarship on those pre-1800 diasporas (see e.g. Carroll 2001, Dillon 2006, Worthington 2010), translation all but disappears as a theme in studies of post-1800 Irish migrants (see e.g. McWilliams and Murray 2018, McWilliams and Walter 2013, Mac Éinrí and O'Toole 2012, and Peatling 2002). Catholic emancipation and the re-routing of Irish migration streams towards transoceanic destinations seem to have created two different kinds of diasporas with all but incommensurable linguistic experiences. One of the main aims of this article is to challenge the rigidity of that divide by shining light on a translator whose origins reflected the pre-1800 world of Irish continental exiles, but whose literary career expanded well into the $19^{\text {th }}$ century and responded to many of the changes that Ireland underwent in that period.

Louise Swanton Belloc (La Rochelle 1796 - Paris 1881) was French by nationality. A prolific woman of letters, she channelled much of her energy into translation work. Her original works and countless reviews and prefaces now belong to the ephemera of $19^{\text {th }}$-century French cultural life, but she is still occasionally remembered and discussed as a respected translator of Englishlanguage classics who introduced works by Charles Dickens, Elizabeth Gaskell and Harriet Beecher-Stowe to French readers ${ }^{1}$, or as the grandmother of the English Catholic writer Hilaire Belloc. However, she also identified as an Irishwoman who cultivated her father's Irish credentials, established contacts with Irish contemporaries, sought out Irish visitors and expatriates in France and - in the early stages of her career, at least - specialized in translating books by Irish authors into French. Swanton Belloc's work as a translator shows that we need not 
always choose between the monolingualism that Cronin imputes to Irish diaspora studies and the focus on translation of his alternative "diffusive perspective" on Irish globalism. Diasporic translation does not have to remain a metaphor in modern Irish studies: it was sometimes an actual practice that can be compared with the activities of other translators who rendered texts from their original culture into the languages of their adopted homelands (see e.g. Simon 2007), even if Swanton Belloc's Irish case is complicated by the fact that her source language was also the medium of other, major literatures.

Louise Swanton was the daughter of James Swanton, a native of Cork $^{2}$. Sent to be educated in France by his widowed mother around 1758, James Swanton had been placed under the patronage of his uncle, the Abbé Swanton, a prominent figure in his French diocese. Having eventually embraced a career in the French army, the young James was enrolled in the 'régiment de Berwick', under the command of the Duke of Fitz-James. By the time of Louise's birth, James Swanton and his French wife Marguerite-Louise Chassériau (related to the Romantic painter Théodore Chassériau) were settled in the garrison town of La Rochelle, and the Irish brigades faced an uncertain future in the revolutionary period.

The semi-retired officer spoke English at home and kept English books in his library. As the child of a diasporic Irishman, Louise Swanton's sense of cultural identity was profoundly marked by her father's language. James Swanton's Catholicism was lightly worn, as he had actually been born a Protestant and had no fond memories of his Catholic education at St Omer (GCPP Parkes 17a/4/5/1, 5); in any case, that Catholicism blended in naturally with French religious life, instead of providing a marker of Irish identity as it did for migrants in the United States or the rest of the British Empire. Ireland was the home of Louise's ancestors, but its most tangible presence in her French home was the English language. This made her feel at home in British or American as well as Irish culture. We will see her identify as English on various occasions, even while she spoke up for Ireland and denounced the wrongs inflicted on her father's homeland. This versatility should not surprise us. In the early $19^{\text {th }}$ century, it was not unusual even for Irish men and women born and bred and with good patriotic credentials to identify alternately as Irish and British/English, especially when they came into contact with the European mainland (see e.g. Ingelbien 2016, 35-38). For Louise Swanton, a second-generation member of the Irish diaspora in France, Irishness and Englishness were perhaps distinct, but clearly not incompatible identities.

The Swanton household moved to Paris in 1815. Regular visitors included James Swanton's old fellow officers of Irish and British Catholic extraction in the Berwick regiment, whose conversation only added to the anglophone atmosphere. Louise Swanton started frequenting French literary circles; over time, she would attend the salons and soirées of Madame de la Villette, Madame Mohl, Victor Hugo and Lamartine among others. Her marriage to the French painter Jean-Hilaire Belloc in 1821 increased her visibility among Paris writers and artists, and ensured that we literally have portraits of this translator, both by her husband and by the sculptor and medallist David d'Angers. Paris under the Restoration was also the haunt of many visitors from the English-speaking world, to whom the perfectly bilingual Louise Swanton Belloc could 
always be of assistance. Her very first assignment as a translator was actually an English version of the visitors' guidebook of the Musée du Luxembourg (GCPP Parkes 17a/4/5/6, 62). This turned out to be the modest beginning of a long career as a woman of letters, in which translation would occupy a central place. If, for some literary-minded women in the period, translation was a stepping stone to creative writing (see e.g. Stark 2006, 127), Louise Swanton Belloc combined both activities for much her life; the disparate nature of her original output (which included educational and moral tales for children, but also a biography of Byron and an essay on Napoleon and Greece) furthermore suggests that it was largely an offshoot of her work as an Anglo-French cultural mediator. Indeed, the themes and genres in which she dealt as an author were contiguous with her translations and reviewing.

Her translation work provided much needed income in the first decades of Louise Swanton Belloc's Parisian life, as neither her own household not her parents' were particularly affluent James Swanton and his wife had suffered financial reverses in the post-revolutionary years (Lépouchard 1994, 16). But she never translated purely for money: her surviving papers and letters show that she selected works herself or only accepted suggestions after careful consideration. She put time and effort into translations, despite the risks involved at a time marked by anglomanie (Chevrel et al. 2012, 420), when competition for French translations of popular English works could be quite fierce:

je ne sais pas, même comme traducteur, aborder des questions sans y avoir pénétré un peu avant; enfin, je crois pouvoir dire que la conscience que j'apporte à mes travaux me les rend plus difficiles et compliqués qu'ils ne le sont pour la plupart de mes confrères. Je ne sais pas me contenter d'à peu près, et c'est une disposition dont je dois me méfier en affaire d'argent et qui m'a souvent rendu onéreux des marchés fort beaux en apparence. (GCPP Parkes 17a/2/7)

[I cannot, even as a translator, tackle issues without having done some research beforehand; what is more, I feel entitled to say that the conscientiousness I bring to my assignments makes them more difficult and complex than they are for most of my peers. I cannot rest content with approximation, and that is a character trait which I must be wary of in terms of business and which has made some apparently lucrative assignments quite onerous to me.]

She agonized over specific texts, as she explained in an 1823 letter to a friend about her translation of poems by Thomas Moore:

j'ai à vous consulter sur ma fatiguante traduction dont je ne suis point contente. Plus je sens les auteurs anglais, moins je suis propre à les traduire. Je ne saurais souffrir d'affaiblir leurs beautés, et sous ma plume elle palissent au point de n'être plus rien... (GCPP Parkes $17 \mathrm{a} / 1 / 2 / 2)$ 
[I wish to consult you about my exhausting translation which gives me no satisfaction. The more I feel English authors, the less I am able to translate them. I cannot bear the thought of weakening their beauties, and when I write they fade into nothingness.]

Her surviving papers further show a tough businesswoman with very little patience with publishers' slights and shortcomings, and who negotiated deals with a high degree of selfconfidence $^{3}$. All this made her a rather atypical translator (Pickford 2012, 150), markedly different from the ill-paid and sometimes anonymous drudges who toiled at translating work in early 19th-century France (139-144).

As her prestige and visibility as a translator grew, Louise Swanton Belloc also increasingly drew attention to the Irishness of the material she translated, mostly through paratextual interventions that occupied an ever more prominent place in the volumes that she presented to French readers. The following discussion will mostly focus on the ways she selected her assignments and framed her translations for French audiences, rather on the textual strategies she pursued in the rendering of English-language originals. Her source language afforded comparatively few opportunities to highlight typically Hibernian traits in translation; as her anxious comments about the beauties of English authors quoted above shows, she made no fundamental distinctions between the idiom of Thomas Moore, whose Melodies caused her such agony, and that of English poets. Prefaces, titles and editorial notes, by contrast, gave the diasporic translator ample scope to educate French audiences about Ireland.

Over time, Louise Swanton Belloc acquired a solid reputation as a French translator of English work. Remarkably, between 1818 and 1841, the major part of her translations concerned Irish authors: she took on several works by Thomas Moore and Maria Edgeworth, as well as single texts by Adelaide O'Keeffe, Thomas Colley Grattan, Richard Lalor Sheil, and Oliver Goldsmith. Within the same period, only four book-length translations by her hand were of writings by nonIrish authors: La Maison d'Aspen (a play by Walter Scott) in 1830, an African travel narrative by English explorers Richard and John Lander (1832), a novel for children by Scottish author Anne Fraser-Tytler (1837), and a treatise on national literature in the United States by the American essayist William Ellery Channing (1838). Her choices were quite eclectic as to genre or theme, but an Irish connection emerges as the most recurrent characteristic of her output.

The very first book that Louise Swanton translated was Patriarchal Times, a re-telling of the Book of Genesis by Adelaide O'Keeffe, the daughter of the Irish actor and playwright John O'Keeffe (Taylor 2009). It was published in Paris in 1818 under the title Les Patriarches, ou la Terre de Chanaan, by "Miss O'Keeffe". The translator's name only appears as "Mlle L** S**": that it was mentioned at all is still no small feat for a first translation, at a time when a modest translator's identity or very existence could go unacknowledged (Chevrel et al. 2012). The publisher Chassériau (a relative of her mother) allowed $\mathrm{L}^{* *} \mathrm{~S}^{* *}$ to dedicate Les Patriarches to her own beloved father, "celui dont toute la vie me rappelle leurs vertus" ["the one whose whole life reminds me of their virtues",] (O'Keeffe 1818, no pagination) but for the rest he provided a 
preface of his own in which he recommended the book to all "amis de la religion et des moeurs" ["friends of religion and morality"] (i). He also had little eye for the Irish connection that the author and the translator shared, as he wrote how "Une Anglaise, inspirée par la lecture des livres saints, a composé cet ouvrage; admiratrice de son beau talent, une jeune Française l'a traduit" ["An English woman, inspired by the reading of scripture, wrote this work, a young French woman translated it"] (i).

Swanton Belloc's second translation was a series of educational tales by Maria Edgeworth (1821). This was the beginning of a long working relationship between the Irish novelist and the French translator, who would in later life present herself as Edgeworth's sole authorized French translator (Lépouchard 1994, 198). Swanton Belloc published many French versions many of Edgeworth's books for children, including twelve volumes collected under the title Education familière (1830). The original tales for children she published under her own name drew inspiration from that work; she once wrote in a letter discussing her educational writings: "Je n'ai même été dans toutes mes tentatives que l'admiratrice, l'interprète et le disciple zélé de Miss Edgeworth" ["In all my endeavours I have only been the admirer, translator and zealous disciple of Miss Edgeworth"] (GCPP Parkes 17a/2/7). Swanton Belloc also started a regular correspondence with Edgeworth, and played host to her great model when the latter visited Paris in 1835 (Lépouchard 1994, 38). As was the case with O'Keeffe, her translations of Edgeworth do not flag any Irish connection. Edgeworth's books for children often had English settings, which the translator, mindful of her young French audience, would often transpose to France. Swanton Belloc only translated one novel by Edgeworth: Helen, which belongs to the more 'English' side of the Anglo-Irish author's fiction (1834). Edgeworth's earlier Irish national tales, it should be noted, had all been translated into French by the time Swanton Belloc turned to translation (Loeber and Loeber, 410-420).

The young translator may have observed contemporary standards of feminine modesty by concentrating on the predominantly 'safe' genres of moral, didactic and/or religious literature. However, as soon as 1823 , she set her sights higher by turning to poetry - and more specifically, to the leading Irish poet of the day, thereby confirming a resolute interest in writing coming out of Ireland. Les Amours des anges, et les mélodies irlandaises by Thomas Moore appeared in 1823 as a 'Traduction de l'anglais par Mme Louise Sw-Belloc, traducteur des Patriarches' ['Translated from English by Mrs Louise Sw-Belloc, translator of Patriarchal Times']. A certain modesty still characterizes her 8-page preface, as she defends her decision to provide only prose translations of a selection of Moore's Irish Melodies:

C'est surtout dans la traduction de ces Mélodies que j'ai regretté de n'être pas poëte, quoique j'eusse peut-être craint d'affaiblir encore davantage le sentiment qui les a dictées, en voulant le plier aux règles de notre versification. Je ne crois pas, je l'avoue, que notre langue pût se prêter à la traduction poétique de ces chants. (4) 
[It is especially when translating those Melodies that I wished I were a poet, although I might have feared lest I further detracted from the emotion that generated them by trying to bend it to the rules of our [French] versification. I admit I do not believe our language can lend itself to the poetic translation of those songs.]

But her admission to lacking poetical gifts is offset by a resolute critique of existing French verse translations of English poetry: Delille's rendering of Paradise Lost, in its cold elegance, strikes her as lacking the original's "grandeur colossale" and "chasteté pleine de simplicité et de noblesse" ["colossal grandeur" and "chastity full of simplicity and nobleness"] (5). She envisions her own prose translation as a help to an appreciation of the original, which she hopes will be made possible by a rapidly growing knowledge of the English language in France (8).

Swanton Belloc's preface to her first translation of Moore also provided her with a first opportunity to expatiate on Irish themes, as she explained how Moore "pleure sur l'Irlande, sa terre natale, et ses pleurs semblent féconder le sol et reproduire des héros: puis reprenant sa lyre, il chante l'espérance, il appelle au combat les descendans de ces guerriers si braves..." ["weeps over Ireland, his native soil, and his tears seem to make the ground fertile and resuscitate heroes : then, picking up his lyre, he sings of hope and calls the descendants of those brave warriors to battle"] (3). Swanton Belloc also highlights the links that unite Ireland and France, in what looks like a tacit nod to her own father's background in the Irish brigades: she quotes Moore as speaking of "les catholiques irlandais à la bataille de Fontenoy, où leur valeur contribua puissamment au succès de la France" ["the Irish Catholics at the battle of Fontenoy, where their valour powerfully contributed to France's success"] (91). Despite those patriotic notes, the preface also speaks of Moore as an English poet: "Moore a créé en anglais une harmonie égale à celle de la langue italienne. Il est le seul des poètes de l'Angleterre qui ait pu opérer cette espèce de prodige" ["Moore has created in English a harmony equal to that of Italian. He is the only English poets who has been able to work that kind of miracle"] (7). Swanton Belloc moreover presents herself as "Elevée par des Anglais, nourrie de la littérature anglaise, surtout de la poésie" ["Brought up by English people, bred on English literature, especially poetry"] (2).

Swanton Belloc's cultivation of an Irish sensibility was not incompatible with a strong identification with the English language in a context marked by the linguistic foreignness of France; Moore's own version of Irish patriotism, moreover, was not predicated on a rejection of English connections (see e.g. Love 2017). On the strength of her first translation of Moore, Swanton Belloc approached the poet to secure exclusive rights to the translation of his forthcoming Memoirs of Lord of Byron (Lépouchard 1994, 73): her own Lord Byron (1824) was humbly presented as a foretaste of Moore's authoritative work: "ce n'est donc qu'en attendant que je me hasarde à publier ceci" ["it is only while waiting that I venture to publish this"] (vi). Such contacts suggest that Swanton Belloc's diasporic sense of Irishness in the early 1820s was still chiefly reflected in a prioritization of work by Irish contemporaries, rather than in any claim to speak of or for Ireland. 
It is not known whether Swanton Belloc personally knew Thomas Colley Grattan, an Irish author who resided in France in the early 1820s. She did however translate one of Grattan's popular series of travel tales High-ways and By-ways, or Tales of the Roadside Picked Up in the French Provinces by a Walking Gentleman. Her long preface defended the outsider Grattan's right to paint portraits of the French countryside, but did not mention his Irish background. Grattan's own original volumes, geared as they were to a British readership interested in France, kept silent about his Anglo-Irish origins. Swanton Belloc's translation, however, flagged Irishness in an indirect way. She faced competition from A.J.B. Defauconpret, the French translator of Walter Scott, who published Contes sur les grandes et petites routes, par un voyageur à pied, concurrently with Swanton Belloc's translation. Interestingly, the latter signalled its difference by highlighting the walking gentleman-author's Irishness in its subtitle: Grandes routes et chemins de traverse. Contes recueillis dans les provinces françaises, par un Irlandais voyageant à pied. Though perhaps chiefly an opportunistic marketing ploy, this focus on the roots that Grattan shared with his translator is also unsurprising in light of the latter's broader strategy.

While Swanton Belloc assiduously translated Irish authors in the 1820s, Ireland was in the thrall of convulsions that attracted considerable attention in Europe. O'Connell's campaign for Catholic Emancipation, which became reality in 1829, the creation of the Catholic Association and the mobilization of Irish popular masses excited much interest. Swanton Belloc had only hinted at those transformations in her book-length translations when, in her preface to the Mélodies irlandaises, she quoted Moore's hopeful glimpse of an "époque plus favorable à la saine politique et à la musique" ["a time more favourable to healthy politics and music"] (Moore 1823, 88). In 1830, however, a volume entitled Scènes populaires en Irlande was published in Paris. The title page mentioned no names whatsoever, but reviews in e.g. the Revue Encyclopédique (a reliable source, as Swanton Belloc was a regular contributor herself) named 'Shiel' [sic] as the author and "mesdames L. Sw.-B. et A. de M." (Louise Swanton Belloc and her friend Adélaïde de Montgolfier) as the translators (Anon. 1830, 748). The book collects French versions of various texts about recent events in Ireland, most of which are attributed to Richard Lalor Sheil, a key figure in the Catholic Emancipation campaign - remarkably enough, the first English-language collection of such pieces would only appear in book form fourteen years later (Sheil 1854). The French volume opens with an unsigned preface of 36 pages which, after a brief introduction to Sheil, presents a short history of Ireland's misfortunes under English rule since the $12^{\text {th }}$ century.

Sheil was not altogether new to French readers: his speeches had been regularly reported in the English press and had found an echo in foreign magazines. The preface praises his role in raising international awareness about the cause of Irish Catholics:

L'éloquence de Shiel [sic], moins populaire que celle d'O'Connel [sic], plus châtiée, plus lettrée , mieux ordonnée dans ses mouvemens, a rendu aussi d'éminens services à la cause de son pays. Elle a aidé à la populariser en Europe. Ses discours, traduits en partie dans nos 
papiers publics, ont arraché des larmes à ceux qui jusque-là séparaient à peine, dans leurs idées , l'Irlande de l'Angleterre. (2)

[Shiel's eloquence, less popular than O'Connell's, more polished, more literate, more disciplined in its movements, has also done great service to his country's cause. It has helped make the latter popular in Europe. His speeches, partly translated in our public papers, have drawn tears from those whose minds hitherto scarcely distinguished Ireland from England.]

The preface also suggests that the volume's editors had themselves translated some pieces for the French press: "nous avions déjà fait paraître des extraits dans le Globe" ["we had already published some extracts in the Globe"] (4). While Swanton Belloc's former translations had sometimes assimilated Irish writing to English literature, she here praises Sheil for distinguishing Ireland from England in the mind of French readers. The French volume shares in the glory of a resurgent Ireland, and the preface closes by praising "la toute-puissance du patriotisme irlandais, la force de la secrète et intime organisation des catholiques et patriotes de toutes croyances, et l'habileté extrême de ceux qui les dirigent" ["almighty Irish patriotism, the strength of the secret and closely knit organisation of Catholics and patriots of all creeds, and the supreme skill of those who lead them"] (35-36).

Scènes populaires en Irlande was unsigned, but references to Swanton Belloc's name in reviews indicate that its translator willingly acknowledged her part in its celebration of her father's homeland. The absence of names on the title page rather suggests a deliberate foregrounding of a collective identity whose celebration took precedence over the individuals involved. In her next two translations of Irish writing (the more 'English' work of Maria Edgeworth excepted), Swanton Belloc would sound patriotic notes with similar assertiveness.

Though specialized in contemporary work, Swanton Belloc was approached by a publisher who wished to bring out a new French translation of Oliver Goldsmith's novel The Vicar of Wakefield (1766). She hesitated, due to challenges she mentions in her short translator's preface: "Entreprendre après M. Charles Nodier une neuvième traduction du Vicaire de Wakefield semblerait un acte d'inexcusable présomption, si je n'avais à dire pour ma défense que je ne connais pas le travail du savant académicien" ["Undertaking a ninth translation of The Vicar of Wakefield after Mr Charles Nodier's would seem unforgiveably presumptuous, if I could not say in my defence that I am not familiar with the learned academician's work'] ${ }^{4}$. Swanton Belloc's 1839 translation offered French readers not just a new text, but also a different apparatus from that of Nodier's 1838 version. It included a short biographical introduction to Goldsmith that Sir Walter Scott had written for English editions of the novel, as well as notes to the text which Belloc mostly based on a recent biography of Goldsmith by James Prior (1837), a Fellow of the Royal Irish Academy. A short editorial note at the end of Scott's text explains that the memoir "en partie de Walter Scott" [partly by Walter Scott] was supplemented with some letters and other information from Prior's biography (Goldsmith 1839, 1x). A comparison with Scott's 
original document reveals extensive additions: Swanton Belloc actually used Scott's text as a Trojan horse to smuggle in all sorts of details about Goldsmith's Irish connections and effectively present him as an Irish author.

Scott's original memoir devotes about a page to Goldsmith's Irish childhood and education (Goldsmith 1828, ix-x), but only twice returns passingly to Ireland afterwards (xiii, xxii). Goldsmith's early Irish years, by contrast, take up twenty pages in Swanton Belloc's heavily reworked version. She also re-introduces Ireland in various passages about his later life. On Goldsmith's continental travels, which provided inspiration for some episodes in The Vicar, Scott writes:

Through Germany and Flanders he had recourse to his violin, in which he was tolerably skilled; and a lively tune usually procured him a lodging in some peasant's cottage for the evening. In Italy, where his music or skill was held in less esteem, he found hospitality by disputing at the monasteries (Goldsmith 1828, xii)

In Swanton Belloc's 'translation', this becomes

En Allemagne et en Flandre, c'est son violon ou sa flûte qui lui valent du pain et un gîte. Parfois aussi il paye de son éloquence et raconte les traditions de son pays natal aux paysans ébahis, comme jadis il l'a vu faire aux bardes errans d'Irlande. Plus d'une fois il poursuivit sur un sol étranger ces émotions de son enfance. ["He sometimes paid with his eloquence and related traditions of his native country to the gaping peasants, as he had once seen done by the wandering bards of Ireland. More than once he pursued those childhood emotions while on foreign soil'] En Italie, où son savoir musical était moins estimé, il allait de couvent en couvent, d'université en université, soutenant des thèses théologiques et philosophiques... (Goldsmith 1839, xxix - my italics for Swanton Belloc's additions)

Swanton Belloc elsewhere mentions that the young Goldsmith had seen performances by the Irish bard Carolan (viii), a detail she found in Prior. In stressing Goldsmith's other affinities with Irish popular culture, she appears to have gone much beyond Prior's factual accounts, as in the following description:

Le maître d'école croyait aux fées, aux brownies, à tout le peuple fantastique qui habite les sauvages bruyères de l'Irlande, cette terre classique des superstitions, où l'on ressent plus d'intérêt à l'histoire des êtres invisibles qu'à celle des hommes de chair et d'os; nation mobile et rêveuse, que le passé et l'inconnu consolent de son triste présent... (vii-viii)

[The schoolmaster believed in the fairies, in the brownies, in all the fantastic crowd that dwells among the wild heaths of Ireland, that classic land of superstition, where stories of invisible people awaken more interest than those of men of flesh and blood; that nation at once mobile and dreamy, who finds solace for her sad present circumstances in the past and the unknown...] 
Swanton Belloc's insistence on Goldsmith's Irishness also colours her endnotes to the novel's text. When the protagonist mentions engaging in philosophical contests on the continent similar to those described above, Swanton Belloc provides a gloss that stresses an Irish diasporic dimension: "Les couvens du continent renfermaient à cette époque bon nombre de moines irlandais, qui ne demandaient pas mieux que de donner le vivre et le couvert à un compatriote, et qui se glorifiaient de le voir triompher dans des thèses philosophiques" ["Continental convents at the time hosted many Irish monks, who were only too happy to give board and lodging to a compatriot, and who gloried in his triumphs in philosophical disputations"] (334).

Swanton Belloc's French readers were thus introduced to a different Goldsmith from the one discussed by previous translators like Nodier, whose preface only mentions Ireland in connection with Goldsmith's birthplace (Goldsmith 1838, 9). While her earlier translations had discussed a self-styled Irish bard like Thomas Moore as alternately Irish and English, she now described Goldsmith, who was largely perceived as an essentially English author, in terms suffused with Irish Romantic patriotism. She next returned to Moore's poetry, and helped present the national bard in a more resolutely Irish guise too.

Chefs-d'oeuvre poétiques de Thomas Moore appeared in Paris in 1841. 'Louise Sw. Belloc' was mentioned as the main translator; her name was followed by the mention of Daniel O'Sullivan, who contributed translations of satirical and burlesque pieces to the volume. O'Sullivan taught English at a prestigious French school and was chief editor of a French series devoted to English writing; he had written a French-language study of English literature and prefaces to French translations of English classics. Swanton Belloc, though, must have spotted the diasporic Irishman in O'Sullivan, who would also go on to publish a book on Irish bards, legends and popular songs (O'Sullivan 1850). Good manners probably dictated the choice of a male translator for Moore's satirical and burlesque poems, but the Irish scholar's erudite literary knowledge could only bolster the volume's focus on Moore as Ireland's national bard and its ambition to enlighten French readers about Irish literature and history.

O'Sullivan's 52-page introduction to Chefs-d'oeuvre alternates sketches of Moore's life and of his connection to Byron with short essays on Irish history, the Irish brigades, and the political dimensions of some of the Melodies, all written from a resolutely nationalist perspective. The essayist explains that Moore cannot be understood without that broader context: "Dans notre crainte de ne pas pouvoir rendre justice à l'auteur, nous préférons placer ici sous les yeux du lecteur une rapide esquisse des principaux événemens de l'histoire de l'Irlande" ("For fear of not doing the author justice, we deem it proper to provide the reader with a short sketch of the main events of Irish history" xiv). Swanton Belloc herself recycled her 1830 prefaces to the Mélodies and L'Amour des Anges and added a new one to her new prose translation of Moore's collection of Oriental poems Lalla-Rookh, preferring to leave patriotic outpourings to her Irish co-editor. The volume as a whole still bears her mark, as most of the translations it contains are from her more experienced hand, and as her name took precedence over O'Sullivan's on the title page. 
Swanton Belloc's 1841 contribution to the French consecration of Moore as Ireland's national poet was to be her last translation of Irish work - if we discount some collections of educational tales by Edgeworth which appeared in Iater decades, often recycling previous translations. In the late 1840s and 1850s, her most notable translations included an 1847 volume of Contes de Noël by Dickens, an authorized translation of one the literary sensations of the early 1850s, La Case de l'Oncle Tom by Harriet Beecher-Stowe, whom Swanton Belloc met personally (Lépouchard 1994, 113-115), and Elizabeth Gaskell's Cranford, which appeared in Paris in 1856. Swanton Belloc's last decades, marked by some periods of ill health, were a fallow period for the translator, although she still wrote French prefaces to English authors and some original tales for children.

This late turn away from Irish material may have had several causes. One might surmise that she gave priority to highly visible authors such as Dickens, Gaskell and Becher-Stowe after having first established her name through less prestigious translations. This would however do anachronistic injustice to the considerable reputations that Edgeworth, Moore and Goldsmith enjoyed in mid- $19^{\text {th }}$ century France. The changes that Ireland underwent in the 1840 s could be another factor. As Irish nationalism grew more radical and factious, and as the Young Ireland firebrands did not rest content with the older generation of patriots' accommodations with the British establishment, Swanton Belloc may have joined some of the prominent Irish liberal supporters of the Catholic Emancipation campaign in their withdrawal from Irish themes ${ }^{5}$. In the diasporic translator's specific case, a double affiliation to the Irish nation and to the English language means she might have felt alienated by emerging separatist, Anglophobic strains of Irish nationalism. However, her patriotic pronouncements do not suggest clear political sympathies beyond a principled defence of Ireland, which had been consecrated by her work on Sheil, Goldsmith and Moore. A more likely explanation lies in the changes that affected her literary contacts in the 1840s and 1850s. With the exception of Goldsmith, Swanton Belloc translated Irish contemporaries. Those she knew best, like Edgeworth or Moore, died in 1849 and 1852 respectively; Sheil died in 1851. Moreover, Irish political crises and the Great Famine of the late 1840s had left English publishers wary of taking on work on Irish themes, popular though these had formerly been: as writers like Anthony Trollope and Joseph Sheridan Le Fanu learned over the next decade, Irish material was out of fashion (Trollope 1994, 1; McCormack 1997, 140). The productions that issued from London printing presses could thus have restricted the Irish diasporic translator's choices.

If Swanton Belloc's public persona became less Irish in her later years, an unpublished family memoir she started penning in 1871 still reveals a strong attachment to her father's homeland. The memoir starts with her beloved father's origins:

Mon père, James Swanton, était né à Cork, en Irlande, sa mère était une miss White, alliée à la famille de Robert Emmet, dont le nom figurait comme parent et témoin dans les actes de 
propriété et l'acte de mariage de miss White avec Godfrey Swanton. (GCPP Parkes $17 \mathrm{a} / 4 / 5 / 1)$

[My father, James Swanton, was born in Cork, in Ireland, his mother was a miss White, related to the family of Robert Emmet, whose name featured as a relative and witness in the title deed and marriage record of Miss White and Godfrey Swanton.]

Swanton Belloc's mention of Robert Emmet (who must have been the father of the more famous, eponymous leader of the 1798 United Irishmen rebellion) stresses her family's Irish patriotic credentials. In that memoir, she also reminisces about meeting various Irish people in France. She praises Lady Morgan, whom she saw in Paris, for the truthfulness of her pictures of Irish life (though Swanton Belloc herself never set foot in the country) and for her love of both an impecunious father and a distressed fatherland:

aimant beaucoup son père ... elle avait embrassé de bonne heure la carrière littéraire dans son désir de lui venir en aide. L'amour de son pays était une autre source d'inspiration où elle avait largement puisé, et qui lui avait valu une réputation méritée. (GCPP Parkes $17 \mathrm{a} / 4 / 5 / 7)$

[as she loved her father after very much ... she had early on embraced a literary career out of a desire to help him. Love of her country was another source of inspiration from which she liberally drew, and earned her a deserved reputation.]

There is something of Swanton Belloc's own history in her record of the Irish author's circumstances. As she made a name for herself, she tellingly preserved at least part of her Irish father's patronym, appearing as 'Mme L(ouise) Sw. Belloc' on the title pages of most of her translations and often signing her letters 'L.Sw.B.' The Irish facet of her identity was never lost, even though it ceased to inform her translating activity half way through an existence that saw her outlive Irish contemporaries by several decades.

Louise Swanton Belloc played a major part in making her French homeland more aware of the variety of Irish writing in English, and of the new causes for which Irish patriots fought and wrote. Comparatively famous though this translator was, she still has not been given a proper a place in scholarship on Franco-Irish relations ${ }^{6}$. Born in France as an old chapter in the history of Irish emigration was concluding, this diasporic translator can generate questions about the contributions of polyglots of Irish birth or descent to the worldwide translation of Ireland in a new era when the diaspora was dominantly, but surely not exclusively rerouted to the Anglosphere. Her involvement in the diffusion of both Irish and 'Anglo-Saxon' writing in France also highlights the potential versatility and paradoxes that inhere in diasporic situations where bilingualism provides an interface between more than two national cultures, and where translation can consequently both find inspiration in and unsettle notions of origins, Irish or other. 
${ }^{1}$ The title of Lépouchard's biography (1994) highlights her relation to English and American cultures, while in a recent discussion Pickford writes of how she adopted "une véritable posture de médiatrice entre les cultures française et anglo-saxonne" [a full-fledged persona as a mediator between French and AngloSaxon cultures] $(2012,150)$.

${ }^{2}$ Biographical information on Swanton Belloc is mostly based on Lépouchard 1994 or, where indicated, on archival material in the possession of Girton College, Cambridge, and referred to here as 'GCPP Parkes 17a'. Acknowledgement is given to The Mistress and Fellows, Girton College, Cambridge for permission to use that material.

${ }^{3}$ See e.g. 'Lettre à Monsieur Eymery, Paris, le 8 août 1825' ; and a letter dated 'Paris, le 1er février 1833' (GCPP Parkes 17a/2/7).

${ }^{4}$ Swanton Belloc underestimates the number for French versions of The Vicar of Wakefield; there were dozens such by the mid-nineteenth century (Lambert and Van Bragt 1980).

${ }^{5}$ On the turn away from Irish themes among novelists like Edgeworth and Lady Morgan after the achievement of Catholic Emancipation, see Lloyd (1993, 134) and Deane (1994, 99). Sheil, whose passionate eloquence for Ireland Swanton Belloc had celebrated in 1830, served in British cabinets in the 1830 s and 1840 s.

${ }^{6}$ Swanton Belloc does not feature in Joannon and Whelan 2017, Reznicek 2017, or Maher and Neville 2004.

\section{References}

Anon. 1830. Review of Scènes populaires en Irlande. Revue Encyclopédique XLVI: 748-749.

Carroll, Clare. 2001. "Custom and Law in the Philosophy of Suarez and in the Histories of O'Sullivan Beare, Céitinn and Ó Cléirigh.” In The Irish in Europe, 1580-1815, edited by Thomas O'Connor, 65-78. Dublin: Four Courts Press.

Chevrel, Yves, Lieven D'hulst and Christine Lombez, eds. 2012. Histoire des traductions en langue française. XIXe siècle (1815-1914). Lagrasse: Verdier.

Cronin, Michael. 2006. Translation and Identity. London: Routledge.

Cronin, Michael. 2008. "Minding Ourselves: A New Face for Irish Studies.” Field Day Review 4: 174185.

Deane, Seamus. 1994. A Short History of Irish Literature. Notre Dame: University of Notre Dame Press.

Dillon, Charles. 2006. "Irish Translation in Continental Europe, 1630-60.” In Irish Communities in Early Modern Europe, edited by Thomas O’Connor and Mary Ann Lyons, 383-394. Dublin: Four Courts Press.

Edgeworth, Maria. 1821. Petits Contes moraux, à l'usage des enfants, en partie traduits librement ou imités de l'anglais de Miss Maria Edgeworth. 2 vols. Paris: A. Eymery and L. Colas.

Edgeworth, Maria. 1828-1834. Éducation familière, ou Séries de lectures pour les enfants, depuis le premier âge jusqu'à l'adolescence, tirées de divers ouvrages de Miss Edgeworth, traduites de l'anglais avec des changemens et additions considérables. Par Louise Sw-Belloc. 12 vols. Paris: Renouard.

Edgeworth, Maria. 1834. Hélène. Traduit de l'anglais par Louise Sw-Belloc. 3 vols. Paris: Ad. Guyot.

GCPP Parkes 17a/1/2/2. Three letters from Louise Swanton Belloc to Adelaide de Montgolfier, 1823. Papers of Louise Swanton Belloc, Girton College, Cambridge. 
GCPP Parkes 17a/2/7. Miscellaneous letters by Louise Swanton Belloc. Papers of Louise Swanton Belloc, Girton College, Cambridge.

GCPP Parkes 17a/4/5/1-10. "Souvenirs et Traditions des Familles Chassériau et Swanton." Unpublished manuscript. Papers of Louise Swanton Belloc, Girton College, Cambridge.

Goldsmith, Oliver. 1828. The Vicar of Wakefield. With a prefatory memoir by Sir Walter Scott. Marburg: Krieger.

Goldsmith, Oliver. 1838. Le Vicaire de Wakefield. Traduction nouvelle par Charles Nodier. Paris: Librairie des Bibliophiles.

Goldsmith, Oliver. 1839. Le Vicaire de Wakefield. Traduction nouvelle par Mme Louise Belloc. Paris: Charpentier.

Grattan, Thomas Colley. 1825a. Contes sur les grandes et petites routes, par un voyageur à pied. Traduit de l'anglais sur la troisième édition, par le traducteur des romans de sir Walter Scott. Paris, Hautecoeur.

Grattan, Thomas Colley. 1825b. Grandes routes et chemins de traverse. Contes recueillis dans les provinces françaises, par un Irlandais voyageant à pied. Traduits de l'anglais sur la troisième édition, par Mme Louise Sw-Belloc. Paris : Renouard.

Ingelbien, Raphaël. 2016. Irish Cultures of Travel. Writing on the Continent, 1829-1914. London: Palgrave Macmillan.

Joannon, Pierre and Kevin Whelan, eds. 2017. Paris - Capital of Irish Culture. France, Ireland and the Republic 1798-1916. Dublin: Four Courts Press.

Lambert, José and Katrin Van Bragt. 1980. The Vicar of Wakefield en langue française: traditions et ruptures dans la littérature traduite. Leuven: KUL. Departement literatuurwetenschap.

Lépouchard, Camille. 1994. Louise Swanton Belloc (1796-1881). Du bon usage des modèles anglais et américains dans les milieux intellectuels français du XIXe siècle. La Rochelle: Rumeur des Ages.

Lloyd, David. 1993. Anomalous States. Irish Writing and the Postcolonial Moment. Durham: Duke University Press.

Loeber Rolf, and Magda Loeber. 2006. A Guide to Irish Fiction, 1650-1900. Dublin: Four Courts Press.

Love, Timothy M. 2017. "Gender and the Nationalistic Ballad: Thomas Davis, Thomas Moore, and Their Songs." New Hibernia Review 21 (1): 68-85.

Mac Éinrí, Piaras and Tina O’Toole, eds. 2012. “New Approaches to Irish Migration.” Éire-Ireland 47 (1).

Maher, Eamonn and Grace Neville, eds. 2004. France-Ireland: Anatomy of a Relationship.Frankfurt-amMain: Peter Lang.

McCormack, W.J. 1997. Sheridan Le Fanu and Victorian Ireland. Stroud: Sutton.

McWilliams, Ellen and Tony Murray, eds. 2018. "Irishness and the Culture of the Irish Abroad." Irish Studies Review, 26 (1). 
McWilliams, Ellen and Bronwen Walter, eds. 2013. "New Perspectives on Women and the Irish Diaspora." Irish Studies Review, 21 (1).

Moore, Thomas. 1823. Les Amours des anges, et les mélodies irlandaises. Traduction de l'anglais par Mme Louise Sw-Belloc, traducteur des Patriarches. Paris: Chassériau.

Moore, Thomas. 1841. Chefs-d'oeuvre poétiques de Thomas Moore. Traduits par Mme Louise Sw. Belloc; Avec une traduction des poésies satyriques et burlesques de Moore, une notice sur la vie et les œuvres du même auteur, par D.[aniel] O'Sullivan. Directeur de la bibliothèque anglo-française, professeur au collège royal de Saint-Louis. Paris: Gosselin.

O'Connor, Anne. 2017. Translation and Language in Nineteenth-Century Ireland. A European Perspective. London: Palgrave Macmillan.

O'Keeffe, Miss [Adelaide]. 1818. Les Patriarches, ou la terre de Chanaan, histoire en tableaux, tirée des saintes Écritures. Traduit de l'anglais, sur la seconde édition, revue et corrigé, par Mlle L** $\mathrm{S}^{* *} .2$ vols. Paris: Chassériau.

O’Sullivan, D[aniel]. 1850. Irlande, poésies des bardes, légendes, ballades, chants populaires, précédés d'un Essai sur ses antiquités et sa littérature. Paris: Sagnier et Bray.

Peatling, G.K. 2002. "Recent Literature on the Irish Diaspora." Studies in Travel Writing 6 (1): 108-126.

Pickford, Susan. 2012. "Traducteurs.” In Histoire des traductions en langue française. XIXe siècle (18151914), edited by Yves Chevrel, Lieven D'hulst and Christine Lombez, 119-157. Lagrasse: Verdier.

Polezzi, Loredana. 2012. “Translation and Migration.” Translation Studies, 5 (3): 345-356.

Prior, John. 1837. The Life of Oliver Goldsmith, M.B. 2 vols. London: John Murray.

Reznicek, Matthew. 2017. The European Metropolis. Paris and Nineteenth-Century Irish Women Novelists. Clemson: Liverpool University Press.

Scènes populaires en Irlande. 1830. Paris: Sédillot.

Sheil, Richard Lalor. 1854. Sketches of the Irish Bar. New York: Redfield, 1854.

Simon, Sherry. 2007. "Diasporic Translation: Klein in Mile End." In Translating Montreal: Episodes in the Life of a Divided City, 58-89. Montreal: McGill-Queen's University Press.

Stark, Susanne. 2006. “Women.” In The Oxford History of Literary Translation in English. 1790-1900, edited by Peter France and Kenneth Haynes, 125-131. Oxford : Oxford University Press.

Sw[anton] Belloc, Louise. 1824. Lord Byron. Paris: Renouard. 3 vols.

Taylor, Clare L. 2009. “O'Keeffe, Adelaide.” Oxford Dictionary of National Biography. Oxford: Oxford University Press.

Trollope, Anthony. 1994. Castle Richmond, edited by Max Hastings. London: The Trollope Society.

Worthington, David, ed. 2010. British and Irish Emigrants and Exiles in Europe: 1603-1688. Leiden: Brill. 